Journal of Southeast Asian

\title{
The SEAAster Scholars Collective: A Story of Homemaking in Academia
}

\author{
Jacqueline Mac \\ Northern Illinois University, jackimacphd@gmail.com \\ Varaxy Yi \\ California State University, Fresno, varaxy@csufresno.edu \\ Vanessa $\mathrm{Na}$ \\ University of California - San Diego, vteck@ucsd.edu \\ Latana Thaviseth \\ Stanford Asian American Activities Center, latana@stanford.edu \\ Malaphone Phommasa \\ University of California, Santa Barbara, mphommasa@ucsb.edu
}

See next page for additional authors

Follow this and additional works at: https://docs.lib.purdue.edu/jsaaea

Part of the Bilingual, Multilingual, and Multicultural Education Commons

\section{Recommended Citation}

Mac, Jacqueline; Yi, Varaxy; Na, Vanessa; Thaviseth, Latana; Phommasa, Malaphone; and Pheng, Linda Marie (2021) "The SEAAster Scholars Collective: A Story of Homemaking in Academia," Journal of Southeast Asian American Education and Advancement. Vol. 16 : Iss. 1, Article 11.

DOI: $10.7771 / 2153-8999.1233$

Available at: https://docs.lib.purdue.edu/jsaaea/vol16/iss1/11

This document has been made available through Purdue e-Pubs, a service of the Purdue University Libraries. Please contact epubs@purdue.edu for additional information.

This is an Open Access journal. This means that it uses a funding model that does not charge readers or their institutions for access. Readers may freely read, download, copy, distribute, print, search, or link to the full texts of articles. This journal is covered under the CC BY-NC-ND license. 


\section{The SEAAster Scholars Collective: A Story of Homemaking in Academia}

\section{Authors}

Jacqueline Mac, Varaxy Yi, Vanessa Na, Latana Thaviseth, Malaphone Phommasa, and Linda Marie Pheng 


\title{
Education and Advancement
}

Vol. 16 Iss. $1(2021)$

\author{
WWW.JSAAEA.org
}

\section{Creative and Literary Works}

\section{The SEAAster Scholars Collective: A Story of Homemaking in Academia}

\author{
Jacqueline Mac ${ }^{a}$, Varaxy $\mathbf{Y i}^{\mathrm{b}}$, Vanessa S. Na ${ }^{\mathrm{c}}$, Latana J. Thaviseth ${ }^{\mathrm{d}}$, Malaphone \\ Phommasa $^{\mathrm{e}}$, and Linda M. Pheng ${ }^{\mathrm{f}}$ \\ ${ }^{a}$ Northern Illinois University, ${ }^{b}$ California State University, Fresno, ${ }^{c}$ University of California, \\ San Diego, 'University of California, Los Angeles, ${ }^{e}$ University of California, Santa Barbara, \\ fUniversity of Wisconsin, Madison
}

\begin{abstract}
How do we make a home in spaces not built for us? What does an academic home for Southeast Asian American (SEAA) women look and feel like? This is the story of how a collective of SEAA women came together to create an alternative space in higher education. Continuing the radical act of resistance modeled by other Black, Indigenous, and women of color scholars, the SEAAster Scholars Collective uses a feminist epistemological approach to further their mission-to advance knowledge and understanding of the postsecondary educational experiences of SEAA students, staff, and faculty.
\end{abstract}

Keywords: Southeast Asian American, women, feminist refugee epistemology, higher education

Please send all correspondence regarding this manuscript to Jacqueline Mac, visiting assistant professor in Higher Education and Student Affairs, Northern Illinois University, jmac@niu.edu 


\section{Introduction}

I don't think I planned on crying last time we talked. But I was wondering what was it about our first conversation that gave me space and trust? One big thing is that I don't necessarily have to explain things. That feeling was emotional for me because it's been a while since I didn't have to do a lot of explaining and still feel heard and still feel seen. So even though I haven't met you [in person], Latana, I feel like I trust you (laughter). I feel like there is a level of trust to open up and share in a vulnerable way.

$$
-J a c k i
$$

In this quote, Jacki shares the visceral impact of a space ${ }^{1}$ where she felt a deep sense of trust and validation. This space represented one of the first group conversations we had that explicitly focused on exploring our experiences as Southeast Asian American (SEAA) doctoral women. It is important to note that this conversation occurred over a video conference and Jacki and Latana had yet to meet in person. Even so, we recognized that something powerful was happening. This essay represents the exploration of what this "something" was and continues to be. We hope that readers engage this piece as a reflection and an attempt to make meaning while we share our story of homemaking in academia.

Our creation of the SEAAster Scholars Collective (further referred to as "the Collective") represents a desire to understand our experiences as SEAAs at the margins, both as sites of oppression and as sites of resistance, empowerment, and transformation (hooks, 2013). The Collective is our home and represents an act of self-determination. We created a space for ourselves in a context where we were not (yet) seen, where our invisibilization and presumed silence is no longer acceptable (Minh-Ha, 1989). By connecting our individual experiences to the larger cultural, socio-historical, and political issues impacting our community, we engage in a homemaking process for ourselves to conduct work that advances social justice for our SEAA communities, especially in higher education.

This essay is about our home and the process of homemaking in academia-what experiences we had, how this process began, what informs our approaches, and what future directions we envision for ourselves and future SEAAster Scholars. In sharing our story, we hope to connect to other SEAA scholars on this journey. We begin by first exploring some of the shared challenges we experienced navigating the academy.

\section{Surviving in the Academy}

In a collaborative autoethnographic project on our racialized and gendered educational experiences as SEAA doctoral women, our reflections revealed three major challenges we faced in our pursuit of the academy: an invisibilization of our identities as SEAA, a devaluation of our research foci on SEAA experiences by others in the academy, and experiences of tensions between our families and communities with our pursuit of the academy ( $\mathrm{Na}$ et al., 2017). We navigated predominantly white educational institutions largely on our own and often as one of the only SEAAs in our

\footnotetext{
${ }^{1}$ In this paper, we use the term "space" to refer to a variety of spaces, such as physical space, virtual space, epistemological space, as well as figurative space.
} 
educational spaces. Some of these experiences have resulted in an enduring sense of isolation. As emerging scholars, practitioners, and activists, we experienced and continue to experience these challenges. As such, we write about these challenges in the present tense to reflect our ongoing experiences in which we simultaneously engage in a healing process.

We readily recall moments when engaging in a classroom discussion or reviewing an assigned reading where Asian and Asian Americans, including SEAAs, are omitted. Along with Pacific Islander, Native, and Indigenous populations, Asian Americans are rarely included in class discussions about student development theory, campus racial climates, access and retention, and other topics related to race and equity in higher education (Museus, 2014). SEAAs are simultaneously positioned on binary extremes of experiencing educational success and requiring little to no support or considered dysfunctional members of society and therefore undeserving of educational support (Ngo \& Lee, 2007; Um, 2003). We often find ourselves trapped within a Black-White binary frame that leaves little space to fully understand and complicate the racialized experiences of SEAAs (Ngo \& Lee, 2007). Because our SEAA identities are invisibilized by our paradigms, curricula, peers, and faculty, we also feel a constant need and responsibility to educate others-including other Asians and Asian Americans-on the histories, community needs, and educational experiences of SEAAs.

We remember when a faculty member shares with us that SEAAs or a specific ethnic subgroup, such as Lao or Khmer students, is too small to focus on for scholarly inquiry. We consistently negotiate with and strategically frame our seemingly narrow work on SEAAs within our research agenda so that others may also find it important. This implicit and explicit discouragement to study SEAA populations, and even Asian American and Pacific Islander populations or communities of color, is not unique to us, but an experience shared by other women of color. Being discouraged to use theories, frameworks, epistemologies, and methodologies that are appropriate to such inquiry also contributes to our experience of SEAA scholarly inquiry being devalued.

We are heavily motivated by our families' and our communities' stories and histories to persist; yet at the same time, we feel burdened by the fear of our inability to honor their sacrifices if we do not succeed in the academy (Kiang, 1996; Museus, 2013). These pursuits often required and continue to require figurative and literal distance from that which motivates us to keep goingour families and communities. Therefore, the decision to continue our pursuit of the academy is nuanced, representing our simultaneous recognition of the privilege that educational opportunity provides and the reflection of the difficult navigation of the educational environments as firstgeneration students and students from refugee families (Covarrubias \& Fryberg, 2015).

Due to these challenges, we constantly question ourselves in the academy. Some questions center on whether we truly deserve to occupy space as an emerging scholar (Clance \& Imes, 1978; Craddock et al., 2011). Other questions focus on making sense of racialized and gendered experiences in everyday academic life such as being confused for other Asian and Asian American women. During particularly exceptional moments, frustration (and rage) arise from being told to pretend we are a different Asian ethnic subgroup because being SEAA was too obscure. This constant questioning is our attempt to make sense of what Gildersleeve et al. (2011) call "an incomprehensible reality" that doctoral students of color face. Such experiences left us feeling isolated, unsure, and longing for a space to be seen, heard, and supported. It is in this longing that we connected with one another. We turn now to the story of how we found each other and began the process of homemaking in academia. 


\section{Finding Each Other and Creating the Collective}

Facing our individual struggles and marginalization within our programs, we longed to find community with other SEAA graduate students. The need to find community and create a space for ourselves in a way parallels how our families and communities sought to build their own neighborhoods and organizations. This was their form of resistance to the marginalization they experienced in society (Võ, 2015). On college campuses, SEAA students sought to create studentinitiated retention programs as a way to build community and find their sense of belonging. These spaces not only allowed students to foster relationships with other SEAA students, but provided an opportunity for students to gain knowledge and develop skills outside of the classroom (Maldonado et al., 2005). Similarly, engaging with community organizations and student-initiated retention programs were part of our shared experiences growing up and as college students. Entering our graduate programs, we understood that finding a community would be important to us. What we did not expect was meeting each other and starting the Collective, a space that would eventually shape our graduate experience and educational trajectories.

The Collective became the student-initiated, community building, space of resistance that we were searching for. It started as a space at conferences where we would come together to share our experiences as SEAA women in academia. We were introduced to each other through mutual colleagues at various conferences. Our conversations often began like this: "One of my classmates told me about you, I heard you were interested in research on Southeast Asians." After learning more about one another, these initial conversations would end with "Finally, someone who gets me and what I'm going through. What conference are you going to next?" As time passed, our conversations extended beyond our graduate school experiences, delving deeper into our relationships with our families, friends, and community. The Collective became our safe space where we felt seen and heard and where we could be our authentic selves. Together, we began to heal. The bond that we developed inspires the name of the collective, SEAAsters, linking together the sisterhood we built and our identities as SEAA women.

The Collective has been very meaningful to us and we desire to share this experience with other SEAA scholars. We made our formal debut as the SEAAster Scholars Collective at the 2016 NASPA Student Affairs Conference in Indianapolis, Indiana. This presentation was the first time we were able to bridge our shared experiences as SEAA graduate women and work on scholarship together. The experience sparked more conversations about how the Collective could continue to serve as a system of support for us and potentially for others. As we progressed through our programs and graduated, we continue to dedicate our capacity to engaging with others and continuing to present, produce, and publish our own scholarship as a Collective. The challenges we faced and are facing as doctoral women did not and do not stop after graduation. As such, our work as a Collective continues to evolve as we do. The Collective is a space for us to share our stories and connect with each other. Today, not only does the Collective provide that space for us, but we transformed it into a space for others. Now, we turn to sharing the epistemological influences that shape how we intentionally foster a space — a home - we have longed sought for ourselves. 


\section{Building a Home and Employing Feminist Refugee Epistemology}

Using a feminist epistemological approach, we commit to advancing scholarship about, with, for, and by SEAA communities. As SEAA women, we approach this work in alignment with the growing body of knowledge theorized and produced by Black, Indigenous, and women of color scholars who seek liberation (e.g., Anzaldúa, 1993; Collins, 1990; Lorde, 1984; Martinez, 2014; Rodriguez, 2006). Indeed, it is liberation we that also seek. We envision home as a site of healing, of life, and of nourishment. It is in these spaces that we sustain our collective energies for pursuing liberation.

Moreover, we center feminist refugee epistemologies (FRE) to describe the ways we enact our politics and desires as complex persons (Espiritu \& Duong, 2018; Tuck, 2009). Initially conceptualized as an alternative approach to the study of refugees, FRE reconceptualized refugee displacement to highlight social reproduction and innovation rather than focus on refugees as a site of rescue (Espiritu, 2014; Espiritu \& Duong, 2018). The tenets of FRE underscore the importance of paying attention to the intersections of private grief and public commemoration, of listening to unsaid things, of relying on emotions, and of looking for the hidden political forces within the sites of intimate domestic and familial interaction (Espiritu \& Duong, 2018). Though we are a generation removed from our families' refugee experiences, we are attempting to reconceptualize and engage in life making processes of our own. Accordingly, we seek to highlight the ways we "invoke the intimate politics of everyday living" as daughters of SEAA refugees pursuing the academy (Espiritu \& Duong, 2018, p. 588).

We engage in intentional life making processes together in several ways. First, we seek relationships with peers who see us and who seek us. In the act of witnessing each other's lives, we see and seek each other's shame, pain, fears, and tears. As daughters, we have witnessed similar emotions and vulnerabilities within our own families as they sought life and livelihood. It is this familiar and intimate relationship with these emotions and experiences of refugeeness that unite us as SEAAs in academia, as women who are committed to honoring these experiences while striving in academia. However, we are not impervious to how academia fosters competition, isolation, and alienation; similarly, these issues are not dissimilar to what our families experienced in creating a new life in the United States. Yet, it is heightened for us as we are often the lone few in our academic spaces. Nevertheless, it is our loneliness that led us to each other. Consequently, we came together to ensure that we are visible not just to each other but to academia. Our coming together, working together, and being together is a political act of survival and resistance. It mirrors the survival and resistance of our communities.

Second, we commit wholeheartedly to the political act of writing to honor voices, memories, stories, and personal agency (Bird, 1998; Martinez, 2014). Having been educated in a system that idolizes an objective "truth" and way of knowing, we are intimately aware that our subjectivities as SEAA women and daughters of refugees are rarely understood and acknowledged. Yet, we are now trained to theorize and explore how these subjectivities shape our understanding of the world. And so, we write together to commemorate our coming together as daughters of refugees committed to elevating our communities' stories. In writing together, we put forth our stories of survival, imagination, experience, and perspectives to heal our traumas and honor our subjectivities (Martinez, 2014). 
Our homemaking process has resulted in a Collective that is founded on values of collectivism and community. It has become both a physical and epistemological space that feels like home. It is an intimate space of sharing of resources and knowledge but also of sharing vulnerabilities, frustrations, and anxieties. It is also a space of celebration. It is in these moments of emotional connection that we continually solidify the foundation of our home. In our own way, in building a home for and among ourselves, we exercise individual and collective agency and empowerment. We commit to making a home in academia to ensure that we can welcome others into this space-so that we can nourish them so they can pursue a livelihood in academia. Our refugee families' stories and our stories depend on not just building a home for ourselves but a community for others. It is in this spirit of collectivism and familial ties that we build this home for the purpose of those who will join us in resistance for liberation.

\section{Envisioning the Future}

We, the SEAAsterScholars, commit to advancing knowledge and understanding of the postsecondary experiences of SEAA students, staff, and faculty. This is our mission as a Collective. Our goals are to raise awareness of SEAA experiences in higher education, to increase understanding and literacy regarding the issues SEAAs face, and to ensure that this knowledge is produced by those within and from our communities.

We pursue these goals in multiple ways. First, we make ourselves visible to others within academic spaces (e.g., classrooms, conferences). We have faced both covert and overt messaging that our research interests are too narrowly focused, in which we are constantly forced to argue why it is important to consider SEAA experiences as it relates to issues of equity and justice. We intentionally seek visibility to ensure that our existence is known. We collectively commit to ensuring that SEAA experiences are included at as many conferences as possible. Since 2016, we have presented on SEAA student issues at over seven different conferences. At each conference, we have the pleasure of connecting with other SEAA individuals who are interested in this work. This is just one of the ways we grow our Collective. Second, we document our collective experiences of engaging, building, and growing this Collective via research and inquiry. We recognize that this space symbolizes our dreams and desires as complex women searching for home. It is also a site of inquiry, rich with ways of knowing, feeling, and being that speak to our humanity and collective pursuit of home. Third, we pursue grant and funding opportunities to sustain our efforts. We utilize the networks available to us to advance our collective work. For example, we have leveraged funding from our individual institutions to support our collective research. Our commitment to growing this Collective is rooted in our desire to create a space for others to feel supported to contribute perspectives rooted in our community's knowledge.

\section{Reflections on Homemaking}

It is through this homemaking process that we make visible and untangle the possibilities of enacting our agency to envision an alternate way of existing collectively in higher education, whether in pursuit of the academy or not. From this process, we offer three reflections and possibilities of homemaking. First, the act of homemaking is physical, emotional, and epistemological. Building a home requires a commitment to showing up and being present in each other's lives. It is the recognition that fostering a collective requires prioritizing the nourishment

of our souls. Engaging in collaborative research serves as one such opportunity for us to work 
through our own understandings of identity, community, trauma, and healing. Second, homemaking recognizes the pain we experience and the healing that must occur. We do not seek to build an idyllic home or all-encompassing structure. In fact, we recognize that "home" can also be a site of pain, trauma, and suffocation (Bui, 2017). Yet, our process of working towards the creation of a home has unearthed a foundation for understanding what it means to be children of refugees, SEAA, the only ones, women, and more. Uncovering these questions and uncertainties render them visible and therefore sites of promise. Finally, homemaking has the opportunity to extend traditional understandings of "home." Our aim is not to replicate rigid structures and doors with the intended purpose to exclude. Instead, the process of homemaking presents opportunities to (un)weave the nourishing aspects of our community spaces and our academic journeys. This process is both ongoing and fluid, as (re)building these spaces requires constant reflection, reflexivity, and negotiation. We call for our SEAA scholar communities who seek home to make home with us in the academy.

\section{References}

Anzaldúa, G. (1987). Borderlands/la frontera: The new Mestiza. Lute Press.

Bird, G. (1998). Breaking the silence. In S. J. Ortiz (Ed.), Speaking for the generations: Native writers on writing. University of Arizona Press.

Bui, T. (2017). The best we could do. Abrams Comicarts.

Clance, P. R., \& Imes, S. A. (1978). The imposter phenomenon in high achieving women: Dynamics and therapeutic intervention. Psychotherapy: Theory, Research \& Practice, 15(3), 241-247. https://doi.org/10.1037/h0086006

Collins, P. H. (1990). Black feminist thought: Knowledge, consciousness, and the politics of empowerment. Routledge.

Covarrubias, R., \& Fryberg, S. A. (2015). Movin'on up (to college): First-generation college students' experiences with family achievement guilt. Cultural Diversity and Ethnic Minority Psychology, 21(3), 420-429. https://doi.org/10.1037/a0037844

Craddock, S., Birnbaum, M., Rodriguez, K., Cobb, C., \& Zeeh, S. (2011). Doctoral students and the impostor phenomenon: Am I smart enough to be here? Journal of Student Affairs Research and Practice, 48(4), 429-442. https://doi.org/10.2202/1949-6605.6321

Espiritu, Y. L. (2014). Body counts: The Vietnam War and militarized refugees. University of California Press.

Espiritu, Y. L., \& Duong, L. (2018). Feminist refugee epistemology: Reading displacement in Vietnamese and Syrian refugee art. Signs: Journal of Women in Culture and Society, 43(3), 587-615. https://doi.org/10.1086/695300

Gildersleeve, R. E., Croom, N. N., \& Vasquez, P. L. (2011). “Am I going crazy?!”: A critical race analysis of doctoral education. Equity \& Excellence in Education, 44(1), 93-114. https://doi.org/10.1080/10665684.2011.539472

hooks, b. (2013). Writing beyond race: Living theory and practice. New York, NY: Routledge.

Kiang, P. N. (1996). Persistence stories and survival strategies of Cambodian Americans in college. Journal of Narrative and Life History, 6(1), 39-64. https://doi.org/10.1075/jnlh.6.1.03per

Lorde, A. (1984). Sister outsider: Essays and speeches. Trumansburg, NY: Crossing Press.

Maldonado, D. E.Z., Rhoads, R., \& Buenavista, T. L. (2005). The student-initiated retention project: Theoretical contributions and the role of self-empowerment. American Educational Research Journal, 42(4), 605638. https://doi.org/10.3102/00028312042004605 
Martinez, S. (2014). "For our words usually land on deaf ears until we scream": Writing as a liberatory practice. Qualitative Inquiry, 20(1), 3-14. https://doi.org/10.1177/1077800413508909

Minh-Ha, T. T. (1989). Woman, native, other: Writing postcoloniality and feminism. Indiana University Press.

Museus, S. D. (2013). Unpacking the complex and multifaceted nature of parental influences on Southeast Asian American college students' educational trajectories. The Journal of Higher Education, 84(5), 708-738. https://doi.org/10.1080/00221546.2013.11777306

Museus, S. D. (2014). Asian American students in higher education. New York, NY: Routledge.

Na, V. S., Yi, V., Mac, J., \& Thaviseth, L. (2017). (Up)Lift as we climb: A collaborative autoethnography of Southeast Asian American women pursuing the academy. In Association for the Study of Higher Education annual meeting. Houston, TX.

Ngo, B., \& Lee, S. J. (2007). Complicating the image of model minority success: A review of Southeast Asian American education. Review of Educational Research, 77(4), 415-453. https://doi.org/10.3102/0034654307309918

Rodriguez, D. (2006). Un/masking identity: Healing our wounded souls. Qualitative Inquiry, 12(6), 1067-1090. https://doi.org/10.1177/1077800406293238

Tuck, E. (2009). Suspending damage: A letter to communities. Harvard Educational Review, 79(3), 409-428. https://doi.org/10.17763/haer.79.3.n0016675661t3n15

Um, K. (2003). A dream denied: Educational experiences of Southeast Asian American youth issues and recommendations. Southeast Asia Resource Action Center and Berkeley Southeast Asian Student Coalition.

Võ, L. T. (2015). Community. In Schlund-Vials, C. J., Võ, L. T., \& Wong, K. S. (Eds.), Keywords for Asian American Studies (pp. 31-36). NYU Press. 


\begin{abstract}
About the Authors
Jacqueline Mac identifies as a first-generation student and as an ethnic Chinese Vietnamese woman. Her dedication to equity and justice work is informed by her family's refugee experiences, heavily shaped by a background in Asian American studies, and drawn from her work as a professional in student affairs and nonprofit sectors. She is a visiting assistant professor of higher education at Northern Illinois University. Jacqueline conducts research to examine race and racism in education, understand the effectiveness of higher education policies and practices, and advance institutional transformation towards equity. She has a particular focus on racially marginalized students, such as Southeast Asian Americans, and the institutions that serve them, also known as minority serving institutions.
\end{abstract}

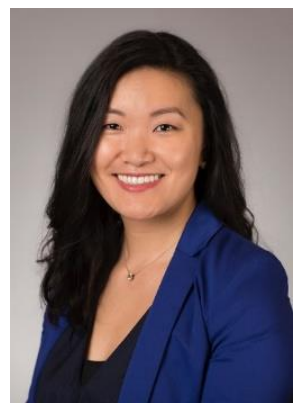

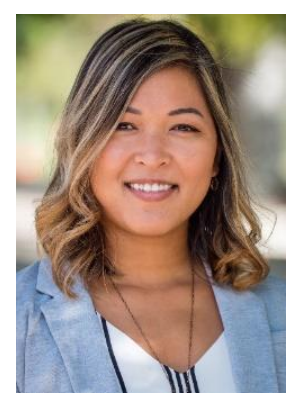

Varaxy Yi is a Khmer American woman, daughter of refugees, and firstgeneration college graduate and faculty. She is an assistant professor in the Department of Educational Leadership at the Kremen School of Education and Human Development at California State University, Fresno. She conducts research to advance equity, access, and opportunity for historically underserved communities, such as racially minoritized, Southeast Asian American, and refugee populations.

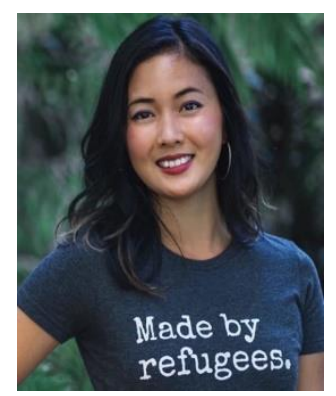

Vanessa S. Na is a Khmer American daughter of a first daughter of a first daughter of refugees. She is a doctoral student in Education Studies at the University of California, San Diego. Her research focuses on the interrogation of and resistance to oppressive logics on college campuses through examinations of race and gender, college student activism, and the formation of solidarities. Vanessa's work contends with neoliberalism's influence on higher education and centers feminist of color epistemologies. She hopes to work towards liberation and honor the work of her communities by cocreating knowledge that is accessible, representative of, and relevant to the communities that she serves.

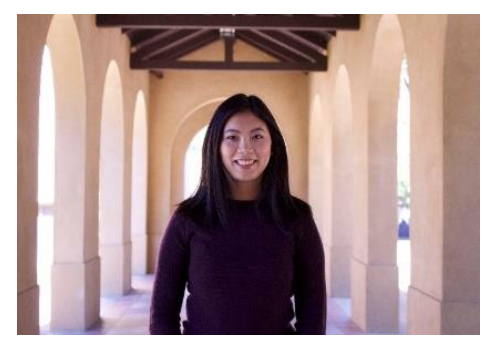

Latana Jennifer Thaviseth identifies as a Lao (Lue/Tai) American woman, first generation college graduate, daughter of refugees, and calls Des Moines, Washington her hometown. She is the assistant director of the Asian American Activities Center at Stanford University and a doctoral student at UCLA. Her research focuses on the educational and occupational trajectories of Southeast Asian American college students. 


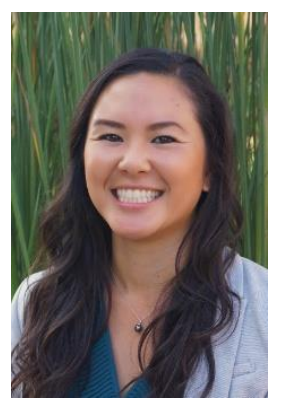

Malaphone Phommasa is a Lao American daughter of refugees and firstgeneration college graduate. Motivated by her identity and dedication to educational access and equity, Malaphone's research focused on the persistence and retention of Southeast Asian American university students. She served as an Assistant Professor, Minority Faculty Fellow at Marshall University in West Virginia before making the conscious decision to leave the faculty route in order to be closer to family and community in Southern California. Malaphone's current role as the Director of Academic Success Initiatives in the Office of Undergraduate Education at the University of California, Santa Barbara allows Malaphone to advocate for first-generation college students, minoritized student populations, and transfer students. As a scholar-practitioner, she continues to navigate what it means to be a firstgen professional.

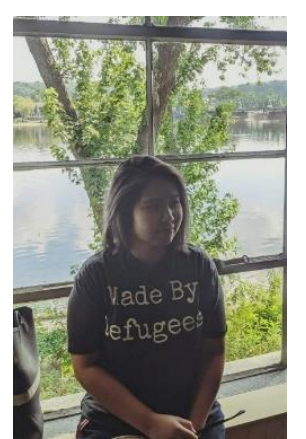

Linda M. Pheng is a Khmer American PhD Candidate in the Department of Educational Policy Studies at the University of Wisconsin-Madison. Grounded in her identity as a daughter of Khmer refugees, her research centers the voices of Southeast Asian American communities to examine the policies, practices, and narratives that frame youths' experiences within schools and out-of-school spaces. She has investigated these areas through various qualitative research projects which make use of a variety of methodologies, including in-depth interviews, participant observations, ethnographic fieldwork, textual analysis, and surveys. Her dissertation project examines how a co-ethnic communitybased organizing youth program works with Southeast Asian American high school youth to cultivate critical consciousness around race and class inequalities in their daily lives. And, in turn, how youth use this knowledge to understand and challenge the educational policy debates and urban reforms that impact their schools, communities, and city. 


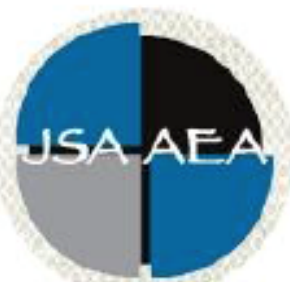

Vol.16 Iss.1 (2021)

\title{
Journal of Southeast Asian American Education and Advancement
}

\author{
Www.JSAAEA.org
}

\section{Editor}

Dr. Wayne E. Wright

Purdue University

Associate Editors

Dr. Chhany Sak-Humphry

University of Hawaii at Manoa

Dr. Phitsamay Sychitkokhong Uy

University of Massachusetts, Lowell

\author{
Book Review Editor \\ Dr. Vichet Chhuon \\ University of Minnesota \\ Creative Works Editor \\ Bryan Thao Worra \\ Lao Assistance Center \\ Journal Manager \\ Chen Li \\ Jeffrey Sovan Wright \\ Purdue University
}

Editorial Review Board

\author{
Dr. Steve Arounsack \\ California State University, Stanislaus \\ Dr. Sovicheth Boun \\ Salem State University \\ Dr. Virak Chan \\ Purdue University \\ Dr. Loan Dao \\ University of Massachusetts Boston
}

\author{
Dr. Carl L. Bankston III \\ Tulane University \\ Dr. Phala Chea \\ Lowell Public Schools \\ Dr. George Chigas \\ University of Massachusetts, Lowell \\ Dr. Hien Duc Do \\ San Jose State University
}




\author{
Dr. Linh Dang \\ KIPP DC Headquarters \\ Dr. Sophal Ear \\ Occidental College \\ Dr. Vincent K. Her \\ University of Wisconsin, Eau Claire \\ Dr. Nancy H. Hornberger \\ University of Pennsylvania \\ Dr. Peter Tan Keo \\ New York University \\ Dr. Yvonne Kwan \\ San Jose State University \\ Dr. Ravy Lao \\ California State University, Los Angeles \\ Dr. Stacey Lee \\ University of Wisconsin, Madison \\ Dr. Jacqueline Mac \\ Northern Illinois University \\ Dr. Bic Ngo \\ University of Minnesota \\ Dr. Leakhena Nou \\ California State University, Long Beach \\ Dr. Mark Pfeifer \\ SUNY Institute of Technology \\ Dr. Loan T. Phan \\ University of New Hampshire \\ Dr. Karen Quintiliani \\ California State University, Long Beach \\ Dr. Angela Reyes \\ Hunter College \\ The City University of New York \\ Dr. Fay Shin \\ California State University, Long Beach \\ Dr. Christine Su \\ College of San Mateo \\ Dr. Alisia Tran \\ Arizona State University \\ Dr. Khatharya Um \\ University of California, Berkeley \\ Dr. Kim Tran \\ University of California, Los Angeles, \\ Glendale Community College \\ Dr. Molly Wiebe \\ The University of Texas at Austin \\ Dr. Changming Duan \\ University of Missouri-Kansas City \\ Dr. Sothy Eng \\ Lehigh University \\ Dr. Jeremy Hein \\ University of Wisconsin, Eau Claire \\ Dr. Peter Nien-Chu Kiang \\ University of Massachusetts, Boston \\ Dr. Kevin K. Kumashiro \\ University of Illinois, Chicago \\ Dr. Ha Lam \\ Independent Scholar \\ Dr. Jonathan H. X. Lee \\ San Francisco State University \\ Dr. Monirith Ly \\ Royal University of Phnom Penh \\ Dr. Sue Needham \\ California State University, Dominguez Hills \\ Dr. Max Niedzwiecki \\ Daylight Consulting Group \\ Dr. Clara Park \\ California State University, Northridge \\ Dr. Giang Pham \\ University of Massachusetts Amherst \\ Dr. Malaphone Phommasa \\ University of California Santa Barbara \\ Dr. Kalyani Rai \\ University of Wisconsin-Milwaukee \\ Dr. Cathy J. Schlund-Vials \\ University of Connecticut, Storrs \\ Dr. Nancy J. Smith-Hefner \\ Boston University \\ Dr. Yer J. Thao \\ Portland State University \\ Dr. Monica M. Trieu \\ Purdue University \\ Dr. Silvy Un \\ Saint Paul Public Schools \\ Dr. Linda Trinh Vo \\ University of California, Irvine \\ Dr. Varaxy Yi Borromeo \\ California State University, Fresno \\ Dr. Yang Sao Xiong \\ The University of Wisconsin-Madison

\section{Dr. Zha Blong Xiong} \\ University of Minnesota
}




\section{Doctoral Student Editorial Review Board}

Diana Chandara
University of Minnesota-Twin Cities
Bao Diep
University of Minnesota-Twin Cities
Vanessa Sovanika Na
University of California San Diego
Khoi Nguyen
George Mason University
Hoa Nha Nguyen
Boston College
Linda Marie Pheng
University of Wisconsin-Madison
Latana Thaviseth
University of California Los Angeles
Melissa Vang
San Diego State University

\author{
Kassandra Chhay \\ University of Minnesota-Twin Cities \\ Annie BichLoan Duong \\ San Joaquin County Office of Education \\ Nielson Hul \\ Cornell University \\ Dung Minh Mao \\ University of Minnesota-Twin Cities \\ Thien-Huong Ninh \\ University of Southern California \\ Krissyvan Truong \\ Claremont Graduate University \\ Mai Vang \\ University of Massachusetts Boston \\ Thong Vang \\ University of Minnesota-Twin Cities
}

Soua Xiong

San Diego State University

Claremont Graduate University 